The book closes with a Tabula gratulatoria, which shows again the esteem and respect towards Dr. Alba felt by many of her colleagues who have not been able to participate in this volume, but have wished to pay a small tribute by having their names included at the end.

In general, it appears difficult to make any suggestion which might have contributed to improving this work, especially given the content of the contributions, all of them of a great quality. However, we feel it important to make a few remarks which we have mentioned above. For instance, this volume contains papers in English and in Spanish in a fairly random way, perhaps because this has been left at the author's choice. In our opinion, this gives the book a slightly disorganized appearance. It might seem that, within the sphere of English studies, it might be better if the papers had been published in the language which is not only the object of study, but also the lingua franca par excellence, which might also contribute to a greater dissemination of the work abroad. Also, a greater coherence might have been reached by a similar number of papers of each of the four sections, or perhaps through a reorganization under different headings allowing for more similar numbers. Nevertheless, it must be admitted that in a volume of this nature, where each author pays tribute to a person by contributing a paper on their specialized field of study, it is not easy to find parallelisms between the sections. It is, therefore, a volume one might describe as plural and heterogeneous, but also a coherent one, since all the papers are related to English studies, the field where Dr. Alba worked, and hence its raison d'être and its consistency as a whole.

Finally, it must be said that the work shows the esteem and warm feelings which Dr Alba has aroused in numerous academics and colleagues during her prolonged academic career. Therefore, this book seems to us a fair sign of recognition in order to pay tribute to a person who has devoted her whole life and work to English studies.

Gerardo Rodríguez Salas. 2009. Katherine Mansfield: el posmodernismo incipiente de una modernista renegada. Madrid: Editorial Verbum. 280pp.

Reviewed by Laura Monrós Gaspar

University of Alicante

Criticism on Virginia Woolf, Kathernie Mansfield and James Joyce has swayed between modernism and postmodernism. Monographs on Woolf's and James' postmodernism abound, yet no such book on Mansfield has ever been published despite the large number of articles and book chapters devoted to the topic. Following in the footstepts of Pamela L. Caughie's Virginia Woolf and Postmodernism: literature in quest and question of itself (1991), Rodriguez-Salas fills part of a scholarly gap by discussing Mansfield's work in light of seminal concepts in postmodern theory such as "the split subject", "intertextuality", "irony", "parody" and "pastiche."

The book is divided into four main chapters and a substantial introduction on modernism and postmodernism which sets the theoretical background for Rodriguez-Salas' analysis. There is a chronology at the beginning of the introduction which locates Mansfield's writing within the modernism/postmodernism debates. Then, the four chapters are organized by theoretical concepts and combine in-depth research, wide reading and grasp on contemporary theory both on postmodernism and on Mansfield criticism. The internal structure of the chapters demonstrates coherent methodology and thematic development. First, the author 
provides an insight into the various definitions of the concept under discussion. Then, the term is considered under Mansfield's lens and finally, case studies of Mansfield's works are provided to demonstrate Rodriguez-Salas' theses. The author quotes extensively from Mansfield and deals with a variety of materials from different sources.

The chapter "El sujeto escindido" develops upon Ihab Hassan's idea of "indetermanence" and the ongoing ontological debate on the identity of the individual as applied to the postmodern subject. Rodríguez-Salas examines the concept of the split subject first in Mansfield's autobiographical writings (letters, diaries...) and then in four main short stories: "The Daughters of the Late Colonel", "The Garden Party", "Je Ne Parle Pas Français" and "A Married Man's Story". Contrary to the Cartesian duality mind-body, the subject in these stories is examined under the perspective of fragmentation, "como una ficción y la idea de performatividad, puesto que tanto la autora como sus personajes construyen constantemente sus personalidades como si estuviesen actuando en una obra de teatro." (29).

Next considered are the ideas of "language", "dogmatism" and "subversive strategies". Silence and paraliterarity intertwine to understand the three concepts under the paradigms of postmodernism. In chapter two, Rodríguez-Salas focuses his analysis on seven short stories: "Weak Heart", "The Doll's House", "The Daughters of the Late Colonel", "The Garden Party", "Je Ne Parle Pas Français”, "Miss Brill and “A Married Man’s Story”. Language and Silence are active subjects in the creation of reality. The two entities are examined by Rodríguez-Salas as tools, in Audre Lorde's words to "dismantle the master's house"; to dismantle a dictatorial and patriarchal system which conceals its individuals.

The book's third chapter centres on intertextuality. Mansfield's intertextuality is analysed in "A Fairy Tale", "In Summer" "The Green Tree: A Fairy Tale", "His Ideal”, "Les Deux Etrangères", "Sun and Moon", "A Suburban Fairy Tale" "The Juniper Tree" and "The Tiredness of Rosabel". Anticipating contemporary works on the reception of fairy tales and classical mythology by women writers such as Carol Ann Duffy, for example, Mansfield rests on fairy tales to subvert orthodox models. The author shows acuity and insight as he discusses and understands the various sources - from Heraclitus to Mark Twain - for each story. Hutcheon, Genette and Bajtin among others provide the theoretical background for this chapter although the book is lacking in contemporary criticism on the reception of the classics, such as the recent $A$ Companion to Classical Receptions (2008) by Lorna Hardwick and Christopher Stray.

Subversion is again the centre of chapter four. "Irony", "Parody" and "Pastiche" are the headings under which the following works are examined: "Taking the Veil", "Violet", "Pictures". Together with language and silence, the three concepts discussed througout become the third essential tool for Mansfield to rewrite Western literature under a feminine lens. Finally, in his summing-up chapter, Rodríguez-Salas argues how marginality is culled as the vertical thread which strengthens the intertexture of horizontal threads that are the postmodern concepts examined throught the book. Marginality is the evidence for locating Mansfield's wrinting within the strong and opositional postmodernism defined by Patricia Waugh, Stephen Best and Douglas Kellner.

Deep knowledge of documentary evidence abounds in Rodríguez-Salas' research yet a conclusion section to clarify and summarize the arguments is missing at the end of each chapter. The book is excellently researched and well written. Detailed evidence for each chapter provides an indispensable, well-informed guide to interpreting and contextualising the work of Katherine Mansfield within postmodernism, while providing a valuable 
contribution to the debate in their own right. Scholars and students of English Literature and Theory will find this book to be an illuminating guide to understanding the complex writing of Katherine Mansfield in light of postmodernism.

\section{Coetzee, J.M (2007). Diary of a Bad Year. London. Harvill Secker. 231 pp.}

\section{Reviewed by José Celestino Nóbrega Correia}

2007 sees two new books on the market by 2003's Nobel Prize winner, J.M Coetzee. First to appear was Inner Workings. Essays 2000 - 2005, followed shortly after by Diary of a Bad year. While the former contains a collection of twenty-one critical essays on works by a wide range of internationally acclaimed authors which evidence Coetzee's personal penchant in reading matter, the latter is his second clear break with South Africa as theme and backdrop to his prose fiction. Elizabeth Costello (2003) may well have initiated this rupture with the turmoil of post-apartheid South Africa, showing unequivocal signs that the author was veering off an old beaten track to follow a new one. However, and even assuming he had already uprooted from his home country to seek new horizons in yet another country, albeit with a colonial past but less turbulent present than South Africa, Elizabeth Costello maintains strong ties with Africa. The severance with South Africa was definitive and a salient feature of Slow Man (2005) which opens with Paul Rayment's biking accident in the environs of Adelaide. All the same, the facetious fictional author, Elizabeth Costello, makes a perturbing appearance here too, unexpected and unannounced to the reader and the protagonist whose life she will disrupt.

Diary of a Bad Year is divided into two parts, the first made up of thirty-one Strong Opinions corresponding to a period between 12 September 2005 - 31 May 2006, while the second part, equally made up of opinions, though of a somewhat softer and more personal nature, goes by the name of Second Diary. In fact, the way the plot is structured, the entire two hundred and thirteen pages serve as a display window for Mr. C, Coetzee's new alter ego's, opinions as well as those of an attractive Filipina neighbour turned personal typist, and Allan, her unscrupulous boyfriend. The spacing of each page is therefore carefully distributed so as to allow for the three characters to opine. Mr C's strong opinions occupy the first section and bulk of the space; for these are the content of the manuscript which he, as fictional an author as Elizabeth Costello, has hired the attractive, jobless Anya to type for him. It will consequently undergo translation and publication in Germany. Mr C overcomes Anya's initial reluctance to undertake the task by offering her rates per hour she could hardly turn down. In the second section of the page $\mathrm{Mr} \mathrm{C}$ gives the reader a first person running commentary of his meetings with Anya, starting on the morning he first set eyes on her in the laundry room of the condominium towers where both reside, till she breaks off with Alan and relocates to another town. Finally a third section, again a first person account, offers Anya's side of the story concerning $\mathrm{Mr} \mathrm{C}$, who becomes a catalyst in the deterioration of her relationship with Alan, especially after he announces his plans to use Mr C's money to enrich himself. Mr C, whose attraction for her she has not been blind to from the outset, grows on her, but Alan resents her holding down a part-time job that he views as a lecherous old man's ruse to maintain her within his grasp, fuelling the erotic fantasies his decrepit body will never fulfil physically. In this third section, at times, Alan's point of view asserts itself over Anya's. 